\title{
THE IMPACT OF GLOBALIZATION ON THE SECURITY ENVIRONMENT
}

\author{
Ionuț Alin CÎRDEI
}

\author{
“Nicolae Bălcescu" Land Forces Academy, Sibiu, Romania \\ cirdei_alin@yahoo.com
}

\begin{abstract}
Globalization is a particularly complex phenomenon that marked the twentieth century and the beginning of the 21st century, bringing about transformations at the level of the entire human society. This phenomenon produces profound, and sometimes irreversible, changes in all areas and imposes an alert rhythm for the existence of all mankind, which must keep pace with globalization in order to maintain its chances of development in an increasingly competitive world. In the last decades, we witness the manifestation of the effects of globalization in the field of individual and collective security, with great implications on the relations between different actors of the security environment. Globalization creates new opportunities, but at the same time it gives rise to new vulnerabilities and allows the emergence of new threats that, once materialized, can have a major impact at a regional or even global level.
\end{abstract}

Keywords: globalization, security, state, threat.

\section{Introduction}

The globalization is a cyclic phenomenon and its motor is represented by the technological breakthroughs that have been able to compress more and more the spatiotemporal dimension, the one that puts the most problems to mankind. This phenomenon is manifested, with less or greater force, in all corners of the world, with greater intensity in developed or developing countries, but without circumventing the less developed societies. Globalization is manifested predominantly in the economic sphere due to commodities, raw materials and labor exchanges, but also in the technological and communications field, due to the development of information technology and the increasing dependence of the mankind on the internet and on modern means of communication. Globalization is a complex process that manifests itself in all areas and produces multidimensional effects. Globalization is not a new concept that marks only the modern age, but refers to a concept that has accompanied human society throughout its entire evolution, embracing different forms adapted to the historical period in which it manifested itself. People's desire to accumulate riches, discover new resources, new territories, expand the influence of some groups, human curiosity were the factors that led to the emergence of this phenomenon. Economic and cultural exchanges were the first manifestations of globalization, and these were followed shortly by military actions, as the expansionary tendency and the clash of cultures and civilizations gave rise to conflicts. Globalization has increased and the process has accelerated over the last decades, being supported by technological development, the emergence of distance communication, increasing the rhythm of life of the whole society.

With regard to the link between globalization and security, we can say that 
due to the increasing interdependencies and the complexity of relations between states, society is transforming, and the multiplication of challenges involves a common approach and shared efforts, because "globalization is the particularly dynamic process of increasing interdependencies between national states as a result of the expansion and deepening of transnational ties in the broader and varied spheres of economic, political, social and cultural life, and implying that problems become more global than national, demanding, in turn, a more global rather than national solution" [1]. Global solutions mean a common understanding of the situation, enhanced cooperation to identify problems and solutions, and sharing efforts to address challenges in all areas, including security.

\section{General aspects of globalization}

Globalization is not an end state in itself, it is not an objective of humanity, globalization is a consequence of the development of society and, at the same time, an engine of it and brings with it a new understanding, a new approach, and at the same time new risks, new vulnerabilities and new opportunities.

Globalization can be seen from three perspectives: from the perspective of uniformity, generalization and differentiation; from the perspective of destruction of entities and the abolition of any frontiers; from the perspective of interconnecting entities, each perspective bringing to the fore new dimensions and features of this complex phenomenon. The globalization process exposes all areas of society to important mutations and generates an increased interdependence of all domains. Globalization is a fact, but its manifestations and consequences are not a fatality, proof being that this cyclical phenomenon accompanies the evolution of human society, determines an adaptation of the whole society and leaps in the development of human civilization.

Globalization implies an expansion of social, political and economic activities across borders, so that events, decisions and activities in a region of the world have significance even for remote individuals and regions of the globe [2]. Globalization is manifested simultaneously in all areas of social life, as shown in Figure no 1, and influences both individuals and states. Influences can not be sequentially limited to one domain, and a comprehensive, multidimensional approach is needed to understand them.

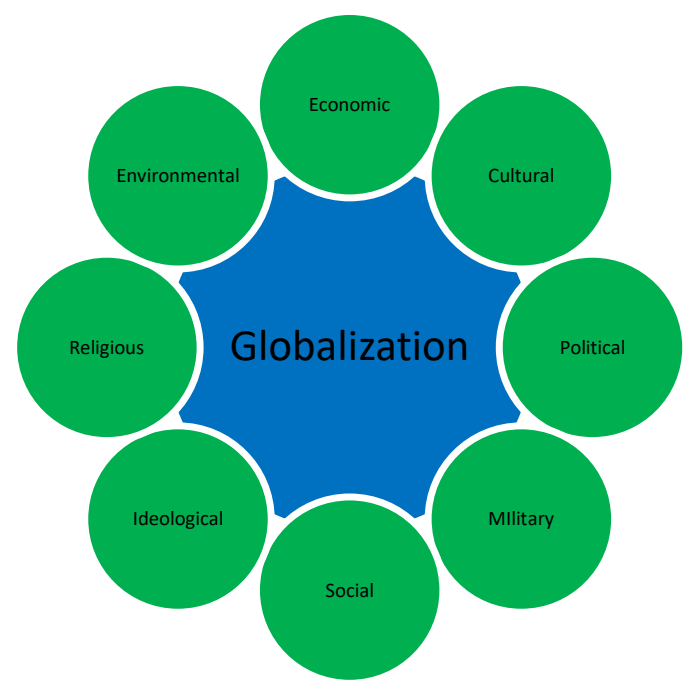

Figure 1: The globalization dimensions 
Globalization as a whole is a phenomenon, a process that can not be either positive or negative. Globalization is a long-term, very complex and non-linear process, with an unevenly accelerated evolution and accompanied by numerous side effects that, unintentionally, can destabilize, even irreversibly, the system.

The positive and negative aspects related to it are determined by how different actors involved in this process relate to it, how they choose to promote their interests and and of many other factors. In essence, globalization can be considered as a catalyst, an amplifier of things, of already existing features. Also, nobody is "protected from globalization," because the effects of this process are felt at individual or state level, and nobody "can isolate itself or remain neutral, no state is safe and none should remain outside the global processes" [3], because it would mean breaking any connections with the outside world and condemning itself to underdevelopment.

The evolution of society from traditionalism to modernism and the complete transformation of the international environment is based on the unprecedented development in the field of technology and information and the modification of the spatio-temporal dimensions, which makes the events develop with much greater dynamics and the information to reach in any part of the globe almost instantaneously. We are witnessing an "accelerated migration of society to the online environment" through the interconnection of social media platforms and smart devices, the implications of which are both in the sphere of individual intimacy and collective security [4].

Expression of this transformation, globalization puts its mark on all areas of social life: economic, military, political, diplomatic, ecological, social, and its effects are contradictory, being both destructive and constructive.

\section{Considerations on globalization of security}

Globalization, being an extremely complex process with multiple ramifications and manifold forms of manifestation, also manifests itself in the field of security, contributing to the creation of a new security environment characterized by the existence of new relations between the different actors, the emergence and the development of new actors, and the emergence of new threats and the multiplication of vulnerabilities, due to the fact that society is more interconnected and interdependent. Globalization in the field of security creates the same paradoxes as in other areas and is accompanied simultaneously by the increase of absolute security relative to other periods and an increase of the sense of insecurity, especially for the population, due to the new threats and the new ways of manifestation of these, correlated with the amplification of vulnerabilities of states, institutions and individuals due to their lifestyle, technology and their increasing dependence on external factors.

Globalization can have positive or negative effects in the areas of economic security, food security, health, physical security, environmental security, community and cultural security, political and military security.

Globalization definitely influences the state of security and amplifies some processes and relationships. What is new in globalized society refers to violence that emits from non-state entities, which generate sources of insecurity that can not be correlated with a particular territory, do not have an exact location, the threat being diffuse, permanent and multidirectional.

Globalization can be reduced to an understanding of the impact that simultaneous integration and fragmentation processes have on society and on safety and security.

In the 21 st century, with the emergence of asymmetric threats, with the development of terrorism, drug trafficking and organized 
crime, we can speak of a globalization of security and also of insecurity, because the global security system functions as a very complex mechanism with infinite connections between the components whose interdependencies are still insufficiently known and whose regulation requires intervention both internally (citizen safety, public order, national security) and externally (national defense and regional and global security). "Globalization also creates opportunities and vulnerabilities for any social entity. Globalization has exposed us to new challenges, changed how old ones have affected our interests and values, but has also visibly improved our ability to respond" [5].

Looking at things from a single perspective, we may be entitled to believe that "globalization is the engine of increasing insecurity" [6], but at a closer look, we can see that globalization reveals the vulnerabilities and forces us to a forwardlooking attitude and to develop a capacity for continual adaptation to environmental or system changes.

"Globalization at once weakens and fragments the state, while militarizing both the state and substate actors, contributing systematically to the emergence of intraand inter-state conflicts" [7].

Opportunities allow the development of the whole society, but at the same time give rise to new vulnerabilities and create new threats, which due to the lesser control that can be exercised by the state acquire new forms of manifestation and are much harder to fight.

Globalization, through its way of manifestation, creates a series of complex mechanisms that manage the interaction between states or other actors of the international environment, either states or non-state actors, and which contributes to the acceleration of all other processes and amplifies the political, economic, political and security interdependencies.

Measuring the relationship between globalization and national and international security is difficult to achieve due to the complexity of interdependencies. As we have said before, globalization offers a new perspective on international relations, different from the reality of the 20th century, which highlights the multitude of perspectives and approaches, as well as the growing number of actors involved. Globalization is neither the cause nor the effect of transformations in the security environment, it is a catalyst for its evolution. In the age of globalization, power is seen differently from the last century. It is no longer about the absolute force exerted by the strongest, but the relative force given by the understanding of the environment and the integration of modern technologies and the adaptation to the new situations and realities. The speed of information circulation, the disappearance of borders, the reduction of the space-time dimension contributes to the creation of the new security environment.

In the context of the security environment transformation, under the impact of globalization, to ensure security and create the conditions for development, each state must find "the optimal combination of integration into the community world and the preservation of national characteristics, the most important factors, which are the signs of identity of this country, to be constituents of the whole world, while remaining important and special part of it" [8].

Globalization is a natural evolution towards a world with permeable borders, a reconsideration of the modern international system based on states. Globalization is neither bad nor good. It will be what the world will want to do from it: a safe way of achieving the common good or a source of dangers for man and his cultural values [9]. The society is moving towards a new stage of globalization of security, which, as in the Cold War, will lead to an intensification of misunderstandings and will lead to a new competition and an arms race. The difference will be that the bipolar world is no longer a solution, a desideratum, existing the tendency to develop a 
multipolar world with regional power centers with contradictory regional interests, defended by states or groups of states with increasing ambitions. At the same time, multipolarity will generate equilibrium but also instability, and maintaining stability and security will be more difficult to achieve due to the multitude of actors and their unpredictability.

\section{The advantages and disadvantages of globalization}

Globalization has many positive effects but also produces negative effects, amplifies inequalities between people and between states, maintains certain conflicts, gives rise to new conflicts, generates new relationships that have developed in the colonial era. Globalization is not a bad thing in itself. More than that "globalization is often seen by its proponents as facilitating a new idealism of economic openness, political transparency, and global culture. Globalization provides an opportunity for the advancement of common human standards and equality as norms and rules are channeled throughout the world. This global proximity is thought to foster cooperation and to increase security" [10].

Its usefulness depends on where we are and how we use it. To understand the phenomenon we need to look at the mechanisms of globalization, whether we agree with it or not.

Globalization is about interests, the attainment of objectives by various means, the imposition of will, opinions, either by using peaceful means, using soft-power specific instruments, or using constraints and violence, through hard power manifestations.

The phenomenon of globalization contributes to the evolution of human society and offers a number of opportunities that can strengthen the state of security. Among the advantages of globalization we can highlight: the development of international trade, which encourages cooperation and maintaining security; increasing capital liquidity and streamlining capital flows, which interconnects states and economies and encourages the overcoming of differences by peaceful means; the flexibility of major transnational companies, which operate in different areas of the world and can influence governments in order to maintain a favorable climate for business development; the global circulation of information, which reduces the possibility of isolation from the rest of the world and concealing of events or actions; global access to technology, which allows the rapid development of most regions; reducing cultural and communication barriers, which allows overcoming prejudices and understanding of other communities; the development and dissemination of democracy and freedom, and this can eliminate dysfunctions in some regions; increasing interdependencies between states, ceea ce implică reducing the risk of conflicts among states; etc.

At the same time, globalization amplifies vulnerabilities and creates and maintains some imbalances, which can turn into sources of instability, inter-state or intrastate tension and even conflict, such as: the relocation of industries to poor countries; migration of intelligence from poor countries to wealthy countries; increasing the role and influence of corporations to the detriment of states; economic and financial interdependencies; important mutations in the value system; erosion of individual and group safety; the spread of local and regional chronic phenomena and manifestations; resource competition; developing organized crime networks; the recurrence of trafficking in human beings and drugs; proliferation of weapons and CBRN assets; development of terrorist organizations; the expansion of ethnic and religious fanaticism; the spread of diseases (in humans, animals and plants); 
the import and export of insecurity and instability; etc.

These manifestations with a potential negative impact are amplified by the phenomenon of globalization, which is a catalyst and process intensifier. Inequalities and imbalances in any region will be amplified by the expansion of globalization, and those who can not fully integrate into global processes will regard globalization as a source of instability and a threat to security.

\section{Conclusions}

Globalization is an irreversible and cyclical process. It will disappear when society enters into a major global crisis that will lead to isolation and self-preservation, seen as solutions to the multitude of threats, or when a destructive war or a planetary cataclysm will bring the end of modern technology.

In the field of security, globalization and interconnection have led states to cooperate, to unite their efforts to overcome barriers and to increase efficiency and security by creating initiatives such as "smart defense". In today's society, globalization of security can translate into adherence to alliances and coalitions to achieve goals or defending shared values, developing standardization and increasing interoperability, sharing resources and capabilities, increased cooperation and overcoming artificial barriers.

In parallel, we can see an amplification of vulnerabilities and a proliferation of threats that affect the general perception of security, such as: developing technologies that allow targets to be hit at great distances; omnidirectionality and permanence of threats; the emergence of new risks and vulnerabilities, the creation of new sources of instability, the disappearance of borders, the emergence of new environments for the manifestation of hostile intentions, such as the cyberspace, the emergence of non-state organizations with regional assertions, the amplification of phenomena such as migration and drug trafficking, proliferation of hybrid threats, etc.

Globalization has a profound impact on the security environment and legitimate actors on the international scene need to focus on identifying vulnerabilities and tackling threats through joint efforts. States are still responsible for ensuring the safety and security of individuals and communities that are largely protected from classical threats but are exposed to new threats, some of them created or amplified by the phenomenon of globalization. Globalization brings new opportunities, but at the same time it can favor the emergence of instability outbreaks and can sustain the amplification of individual or collective insecurity.

\section{References}

[1] Ioan BARI, Probleme globale contemporane, Editura Economică, Bucureşti, 2003, p. 37.

[2] Dorel BUȘE, Geopolitică și geostrategie, Editura Universității Naţionale de Apărare "Carol I", București, 2012, p. 167.

[3] Marius PRICOPI, Globalization of insecurity - a determining factor for the European defense integration, in The 18th international conference The knowledge based organization (vol I), Conference proceedings 1, Management and military sciences, Land Forces Academy Publishing House, Sibiu, 14 - 16.06.2012, p. 108.

[4] Laviniu BOJOR, Security and Privacy in Smart Devices Era, International conference KNOWLEDGE-BASED ORGANIZATION, Volume 23: Issue 1, 20 Jul 2017, pp. 4452, accesed at https://doi.org/10.1515/kbo-2017-0007.

[5] Teodor FRUNZETI, Alexandra SARCINSCHI, Vulnerabilități, amenințări și riscuri în sistemul global, în dr. Teodor Frunzeti, dt. Vladimir Zodian (coordonatori), Lumea 2007 - enciclopedie politică și militară, Editura CTEA, București, 2007, p. 39. 
[6] Alexandra SARCINSCHI, Globalizarea insecurităţii. factori şi modalităţi de contracarare, Editura Universității Naționale de Apărare "Carol I", București, 2006, p. 27.

[7] Mosaddeq Ahmed NAFEEZ, The globalization of insecurity: how the international economic order undermines human and national security on a world scale, HAOL, Núm. 5 (Otoño, 2004), 113-126, p. 113, accessed at https://historiaactual.org/Publicaciones/index.php/hao/issue/view/5.

[8] Sharif KABILOV, Globalization and security, International Journal of Current Research, 8,(11),2016,pp.41971-41973 accessed at http://www.journalcra.com/article/globalizationand-security.

[9] Cornel DINCO, Filofteia REPEZ, Gheorghe DEACONU, Securitate și insecuritate în era globalizării, Editura Universității Naționale de Apărare "Carol I", București, 2011, p. 80.

[10] Sean KAY, Globalization, Power, and Security, Security Dialogue vol. 35, no. 1, March 2004, p. 10. https://journals.sagepub.com/toc/sdib/35/1. 